\title{
Komunikasi Efektif Sebagai Upaya Penanggulangan Bencana Alam di Kota Padangsidimpuan
}

\author{
Sigit Hardiyanto, Darmansyah Pulungan \\ Universitas Muhammadiyah Tapanuli Selatan \\ e-mail: sigit12hardiyanto@gmail.com
}

\begin{abstract}
Natural disasters is a natural events that results in a big impact for of human populations. The city padangsidimpuan hit by natural disaster flooding due to heavy rain has made the rivers to overflow and as a result sweeping stems ayumi houses on the outskirts of rivers and result in casualties died .Regional disaster management agency ( bpbd) padangsidimpuan city is one of the most important factors in make a difference to the society about preparedness to natural disasters in their areas. Of the study which used in this case study qualitative wear with the approach .The source of information in this review are personnel ( bpbd) and city people padangsidimpuan. The results indicate communication verbal effective both effective and non verbal effective need to and must be intense will not cease to be done to make the processes of communication that is konatif can work well. Expected bpbd city padangsidimpuan and the community communicating intense that they know will things grows about about natural disasters and preserving environment not make waste to rivers and not cutting trees illegally loging .
\end{abstract}

Key Word: Effective communication, the natural disaster management

\begin{abstract}
Abstrak
Bencana alam adalah suatu peristiwa alam yang mengakibatkan dampak besar bagi populasi manusia. Kota Padangsidimpuan mengalami bencana alam banjir akibat hujan deras yang mengakibatkan sungai Batang Ayumi meluap dan akibatnya menyapu rumah-rumah di pinggiran sungai serta menimbulkan korban jiwa meninggal dunia. Badan Penanggulangan Bencana Daerah (BPBD) Kota Padangsidimpuan merupakan salah satu faktor terpenting dalam memberi pengaruh kepada masyarakat terkait kesiapsiagaan terhadap bencana alam di daerahnya. Kajian yang digunakan dalam hal ini memakai kualitatif dengan pendekatan studi kasus. Narasumber dalam kajian ini adalah Personil (BPBD) dan masyarakat Kota Padangsidimpuan. Hasil Kajian menunjukkan komunikasi efektif baik verbal efektif maupun non verbal efektif perlu dan harus senantiasa intens dilakukan agar proses komunikasi yang bersifat konatif dapat berjalan dengan baik. Diharapkan BPBD Kota Padangsidimpuan dan masyarakat melakukan komunikasi intens agar masyarakat tahu akan hal-hal berkembang mengenai seputar bencana alam serta memelihara lingkungan tidak membuat sampah ke sungai serta tidak melakukan penebangan pohon secara liar.
\end{abstract}

Kata Kunci : Komunikasi Efektif, Penanggulangan Bencana Alam 
Latar Belakang Masalah

Bencana alam adalah suatu peristiwa alam yang mengakibatkan dampak besar bagi populasi manusia. Padangsidimpuan akhir-akhir ini terjadi bencana longsor terjadi di kelurahan Wek Dua, Lingkungan Lima, Silayang-layang, banjir di yang baru- baru ini terjadi di Kecamatan Padangsidimpuan Selatan Kota Padangsidimpuan. Banjir akibat hujan deras juga mengakibatkan sungai Batang Ayumi meluap dan akibatnya menyapu rumah-rumah di pinggiran sungai. Puluhan rumah dan kendaraan rusak akibat banjir tersebut dan bahkan ada beberapa jumlah korban meninggal dunia akibat banjir yang terjadi akhir-akhir ini.

Bencana menurut UndangUndang Nomor 24 Tahun 2007 tentang penanggulangan bencana adalah peristiwa atau rangkaian peristiwa yang mengancam dan mengganggu kehidupan dan penghidupan masyarakat yang disebabkan, baik oleh faktor alam dan/atau faktor nonalam maupun faktor manusia sehingga mengakibatkan timbulnya korban jiwa manusia, kerusakan lingkungan, kerugian harta benda, dan dampak psikologis.

Dalam mengatasi banyaknya korban jiwa pada sebuah peristiwa bencana alam, maka sangat diperlukan strategi yang tepat untuk mengatasi peristiwa tersebut, salah satu nya melalui komunikasi. Dewasa ini keberadaan komunikasi merupakan ilmu dan aktivitas semakin disadari sangat penting dilakukan manusia. Sebagai manusia yang hidup dan berinteraksi dengan manusia lainnya. Sejak lahir sampai akhir kehidupan, manusia tidak terlepas dari komunikasi. Apalagi komunikasi ini timbul akibat adanya kebutuhan seperti kebutuhan rasa aman baik terhadap diri sendiri maupun orang lain.

Komunikasi efektif (Uripni; 2003) adalah komunikasi yang mampu menghasilkan perubahan sikap (attitude change) pada orang yang terlibat dalam komunikasi. tujuan komunikasi efektif adalah memberi kemudahan dalam memahami pesan yang disampaikan antara pemberi dan penerima sehingga bahasa lebih jelas, lengkap, pengiriman umpan balik seimbang dan melatih penggunaan bahasa 
nonverbal secara baik. Bentuk dan karakteristik komunikasi efektif adalah mencakup komunikasi verbal efektif dan nonverbal efektif.

Komunikasi verbal efektif mempunyai karakteristik jelas dan ringkas, perbendaharaan kata mudah dimengerti, mempunyai arti denotatif dan konotatif, intonasi mampu memengaruhi isi pesan, kecepatan berbicara yang memiliki tempo dan jeda yang tepat serta ada unsur humor. Sedangkan komunikasi non verbal dapat disampaikan melalui beberapa cara yakni penampilan fisik, sikap, tubuh, dan cara berjalan, ekspresi wajah dan sentuhan.

Terkait dengan bencana alam, kajian komunikasi yang digunakan adalah melalui kajian komunikasi bencana. Istilah komunikasi bencana belum menjadi konsep popular dalam bidang komunikasi maupun bidang kebencanaan, meski penelitian komunikasi bencana sendiri telah banyak dilakukan, namun di Indonesia kajian komunikasi terkait bencana baru banyak dilakukan setelah peristiwa bencana alam gempa dan Tsunami di Aceh. meski demikian, kesadaran akan pentingnya komunikasi dalam penanganan bencana semakin tinggi belakangan ini. salah satu titik penting yang menjadi perhatian terkait komunikasi dalam bencana adalah masalah ketidakpastian. menurut Frank Dance (Littlejohn; 2006), salah satu aspek penting di dalam komunikasi adalah konsep reduksi ketidakpastian. komunikasi itu sendiri muncul karena adanya kebutuhan untuk mengurangi ketidakpastian, supaya dapat bertindak secara efektif demi melindungi atau memperkuat ego yang bersangkutan dalam berinteraksi secara individual maupun kelompok. dalam penanganan bencana, informasi yang akurat diperlukan oleh masyarakat maupun lembaga swasta yang memiliki kepedulian terhadap korban bencana.

Menurut Haddow dan
Haddow (2008) terdapat empat
landasan utama dalam membangun
komunikasi bencana yang efektif
yaitu:

1. Costumer focus, yaitu memahami informasi apa yang dibutuhkan oleh pelanggan dalam hal masyarakat dan relawan. Harus dibangun mekanisme 
komunikasi yang menjamin informasi disampaikan dengan tepat dan akurat

2. Leadership comitment, pemimpin yang berperan dalam tanggap darurat harus memiliki komitmen untuk melakukan komunikasi efektif dan terlibat aktif dalam proses komunikasi.

3. Situasional awareness, komunikasi efektif didasari oleh pengumpulan, analisis dan diseminasi informasi yang terkendali bencana. Prinsip komunikasi efektif seperti transparansi dan dapat dipercaya meenjadi kunci.

4. Media partnership, media seperti televisi, surat kabar, radio dan lainnya sangat penting untuk menyampaikan informasi secara tepat kepada publik. Kerjasama dengan media menyangkut kesepahaman tentang kebutuhan media dengan tim yang terlatih untuk bekerjasama dengan media untuk mendapatkan informasi dan menyebarkannya kepada publik.

\section{Metode Penelitian}

Kajian penelitian ini termasuk jenis penelitian kualitatif dengan focus kajian terutama mengenai bagaimana komunikasi efektif dalam penanggulangan bencana alam di Kota Padangsidimpuan.Penelitian ini menggunakan studi kasus sebagai kajian rinci atas suatu latar atau peristiwa tertentu. Robson (dalam Idrus, 2009) mengatakan bahwa studi kasus sebagai suatu strategi untuk melakukan penelitian. Ary (Idrus, 2009) juga mengatakan bahwa studi kasus adalah penyelidikan intensif seorang individu, namun studi kasus juga dapat dipergunakan untuk menyelidiki unit-unit sosial yang kecil seperti keluarga, sekolah, kelompok-kelompok dan geng anak muda.

Dalam pendekatan studi kasus, biasanya seorang peneliti akan meneliti satu individu atau unit sosial tertentu secara mendalam. Dengan begitu, peneliti berusaha menemukan semua variabel penting yang terkait dengan diri subjek yang diteliti. Selain itu peneliti juga meneliti bagaimana perkembangan diri subjek, penyebab terjadinya hal tersebut, perilaku keseharian subjek 
dan alas an perilaku itu dilakukan, serta bagaimana perilaku berubah dan penyebab terjadinya perubahan perilaku tersebut (Idrus, 2009).

\section{Hasil Penelitian dan Pembahasan}

Bencana yang sering terjadi di Kota Padangsidimpuan diantaranya tanah longsor dan banjir. Misalnya tanah longsor yang terjadi di Tanggal dan Silayang-Layang tahun 2015, meskipun tidak ada korban jiwa namun sebagian rumah hancur akibat tanah longsor tersebut. Selain itu banjir bandang yang tejadi tanggal 26 Maret 2017 yang terjadi pukul 18.00 WIB silam yang mengakibatkan 7 orang tewas hanyut, puluhan rumah dan kendaraan hanyut diterjang banjir bandang. Faktor yang menyebabkan terjadinya banjir adalah curah hujan yang cukup tinggi serta pembukaan lahan dan akibatnya banyak kepala keluarga kehilangan tempat tinggal dan harta benda kemudian tinggal diposko pengungsi sementara. Bisa dikatakan demikian karena dapat dilihat dari kondisi geografisnya bahwa Kota Padangsidimpuan diapit oleh bukit-bukit.
Komunikasi berlangsung efektif, sederhana, pendek dan langsung. makin sedikit kata-kata yang digunakan, makin kecil kemungkinan terjadi kerancuan. kejelasan dapat dicapai dengan berbicara secara lambat dan mengucapkannya dengan jelas. pengunaan contoh bisa membuat penjelasan lebih mudah dipahami. penerima pesan perlu mengetahui apa, mengapa, bagaimana, kapan, siapa dan dimana. ringkas menggunakan kata-kata yang mengekspresikan ide secara sederhana. Misalnya menginformasikan kepada masyarakat mengenai bencana meskipun tidak bisa mengelakkan bencana, tidak tau kapan datangnya bencana setidaknya masyarakat bisa menyelamatkan diri dan bisa tahu mengenai tanda-tanda bencana akan datang atau setelah sosialisasi dan simulasi pihak BPBD Kota Padangsidmpuan memberikan nomor telepon untuk bisa menghubungi pihak BPBD Kota Padangsidimpuan.

Penggunaan kata-kata yang mudah dimengerti oleh masyarakat. komunikasi tidak akan berhasil jika pengirim pesan tidak mampu 
menerjemahkan kata dan ucapan.

Dalam hal ini bahasa atau kata-kata yang sering digunakan untuk melakukan komunikasi menggunakan kata-kata sehari-hari serta diperkuat dengan menggunakan bahasa Batak sebagai alat komunikasi BPBD dengan masyarakat agar tidak mengakibatkan hambatan komunikasi yang bersifat semantik

Intonasi suara komunikator mampu memengaruhi arti pesan. Nada suara pembicaraan mempunyai dampak besar terhadap arti pesan yang dikirimkan karena emosi seseorang dapat secara langsung memengaruhi nada suaranya. BPBD Kota Padangsidimpuan dalam hal ini intonasi perlu digunakan dalam penyampaian pesan kepada masyarakat agar pesan yang disampaikan bersifat peneguhan dan penekanan yang hasilnya akan memberi dampak konatif yang dilakukan oleh BPBD Kota Padangsidimpuan kepada masyarakat.

Kecepatan berbicara bukan merupakan keberhasilan dalam komunikasi verbal. Hal ini dapat membingungkan komunikan dalam menerima pesan. Berbicara perlahan tetapi pasti lebih efektif dibandingkan berbicara dengan cepat karena masyarakat akan dapat mencerna lebih baik apa yang disampaikan BPBD Kota Padangsidimpuan kepada masyarakat dalam hal informasi bencana alam.

Humor dapat meningkatkan keberhasilan komunikator dalam memberikan dukungan emosional terhadap komunikan. Dugan (Uripni; 2003) menyatakan bahwa tertawa membantu mengurangi ketegangan dan rasa sakit yang disebabkan oleh stress. Humor yang diberikan oleh BPBD Kota Padangsidimpuan antara lain misalnya membuat permainan kata contohnya pihak BPBD Kota Padangsidimpuan saat memberikan informasi kepada masyarakat menginformasikan gempa, masyarakat langsung keluar sambil memegang kepala atau contoh yang lainnya membuat games yang mendidik masyarakat akan tanggap bencana agar terkesan tidak kaku dalam penyampaian pesan yang dilakukan oleh Badan Penanggulangan Bencana Alam Kota Padangsidimpuan kepada masyarakat 
sehingga hasilnya masyarakat pun merasa terhibur.

Sementara itu penampilan fisik dapat mempengaruhi komunikan. penampilan merupakan salah satu hal pertama yang diperhatikan selama komunikasi. Kesan pertama dalam 20 detik sampai empat menit pertama. Delapan puluh empat persen dari kesan seseorang berdasarkan penampilannya. Bentuk fisik, cara berpakaian dan berhias menunjukkan kepribadian, status sosial, pekerjaan, agama, budaya dan konsep diri. Penampilan merupakan hal terpenting yang harus dilakukan BPBD Kota Padangsidimpuan sebelum mereka memberikan informasi kepada masyarakat karena penampilan itu merupakan syarat dan modal utama untuk membangun kepercayaan kepada masyarakat saat memberikan informasi baik lisan maupun tulisan,

Sikap tubuh dan cara berjalan. Sikap tubuh dan cara berjalan mencerminkan konsep diri, alam perasaan $(\mathrm{mood})$ dan kesehatan. Penampilan mungkin adalah sumber informasi tunggal yang paling penting dalam membentuk pesan permulaan. Barangkali bukti paling dramatis dari arti penting penampilan datang dari studi tentang pilihan kencan, dimana daya tarikmerupakan faktor yang sangat penting ketimbang faktor-faktor lain seperti agama, wajah, harga diri, prestasi, akademik, bakat, kepribadian, dan popularitas, dalam menentukan setingkat apa individu lawan jenis akan saling tertarik. Bukti dari penelitian lain menunjukkan bahwa daya tarik fisik tidak hanya penting untuk preferensi kencan tetapi juga sering merupakan prediksi kesuksesan, keterkenalan, keramahan, daya tarik seksual, kredibilitas dan bahkan juga menentukan bagaimana kebahagiaan orang tersebut. Sejumlah faktor yang berkontribusi terhadap penampilan, diantaranya adalah rambut, pakaian, fisik, perhiasan dan artefak (Ruben dan Stewart; 2013).

Ekspresi wajah merupakan bagian tubuh yang paling ekspresif. Hasil penelitian menunjukkan enam keadaan emosi utama yang tampak melalui ekspresi wajah, yakni terkejut, takut, marah, jijik, bahagia dan sedih. Ekspresi wajah sering digunakan sebagai dasar penting 
dalam menentukan pendapat interpersonal. Kontak mata juga sangat penting dalam komunikasi. Ekspresi wajah yang diberikan BPBD Kota Padangsidimpuan kepada masyarakat ketika memberikan informasi dengan tulus, bahagia dan senang karena menginformasikan kepada publik mengenai bencana merupakan sebuah ibadah yang dilakukan Badan Penanggulangan Bencana Daerah Kota Padangsidimpuan karenaa hal ini juga menyangkut nyawa seseorang ketika datangnya bencana alam.

Pakaian memenuhi sejumlah fungsi bagi kita sebagai manusia, termasuk dekorasi, perlindungan fisik dan psikologis, daya tarik seksual, pernyataan diri, penyangkalan diri, penyembunyian, identifikasi kelompok dan menampilkan status atau peran. Kosmetik, perhiasan batu permata, kacamata, tato, kepangan rambut, buli mata palsu, dan tindikan pada tubuh juga banyak digunakan untuk tujuan tersebut (Ruben dan Stewart; 2013; 2013). Pakaian yang digunakan oleh Badan Penanggulangan Bencana Alam Kota
Padangsidimpuan merupakan style mempengaruhi masyarakat dalam penyampaian pesan komunikasi dan pakaian yang sering digunakan oleh BPBD Kota Padangsidimpuan terbagi menjadi 2 jenis yakni pakaian di lapangan (PDL) yang bewarna orange topi bewarna hitam dengan nama BPBD listorange di tengah kemudian pakaian kantor (PDH) bewarna krem. Sebelum memberikan informasi kepada masyarakat pimpinan BPBD Kota Padangsidimpuan selalu mengingatkan untuk selalu menggunakan atribut saat memberikan informasi kepada masyarakat agar masyarakat percaya bahwa informasi tersebut memang bersumber dari personil BPBD Kota Padangsidimpuan

Upaya yang harus dilakukan oleh masyarakat dalam menangani bencana adalah dengan dilakukan tindakan preventif misalnya tidak menebang pohon sembarangan (ilegal loging), memberikan sosialisasi serta simulasi dan bersahabat dengan alam dengan cara menjaga kebersihan dengan tidak membuang sampah ke sungai juga 
merupakan upaya yang harus

dilakukan oleh masyarakat.

\section{Penutup}

Komunikasi yang dilakukan oleh BPBD Kota Padangsidimpuan dalam meminimalisir korban jiwa atas peristiwa bencana alam telah berlangsung secara efektif, sederhana, pendek dan langsung. Informasi yang diberikan kepada masyarakat mengenai bencana meskipun tidak bisa mengelakkan bencana, tidak tau kapan datangnya bencana setidaknya masyarakat bisa menyelamatkan diri dan bisa tahu mengenai tanda-tanda bencana akan datang atau setelah sosialisasi dan simulasi pihak BPBD Kota Padangsidmpuan memberikan nomor telepon untuk bisa menghubungi pihak BPBD Kota Padangsidimpuan.

Penggunaan kata-kata yang mudah dimengerti oleh masyarakat, intonasi suara yang mampu memengaruhi arti pesan, berbicara perlahan tetapi pasti lebih efektif dibandingkan berbicara dengan cepat karena masyarakat akan dapat mencerna lebih baik apa yang disampaikan BPBD Kota Padangsidimpuan kepada masyarakat dalam hal informasi bencana alam, serta dibarengi dengan penyampaian pesan yang tidak monoton tetapi dibarengi dengan aktifitas permainan atau kegiatan humor lainnya.

Sementara itu dalam hal komunikasi nonverbal, pihak BPBD Padangsidimpuan menerapkannya melalui penampilan fisik, sikap tubuh dan cara berjalan, ekspresi wajah dan pakaian. Dalam melakukan upaya meningkatkan kesiapsiagaan masyarakat kota Padangsidimpuan, melalui aktifitas sosialisasinya, pakaian yang sering digunakan oleh BPBD Kota Padangsidimpuan terbagi menjadi 2 jenis yakni pakaian di lapangan (PDL) yang bewarna orange topi bewarna hitam dengan nama BPBD listorange di tengah kemudian pakaian kantor (PDH) bewarna krem. Sebelum memberikan informasi kepada masyarakat pimpinan BPBD Kota Padangsidimpuan selalu mengingatkan untuk selalu menggunakan atribut saat memberikan informasi kepada masyarakat agar masyarakat percaya bahwa informasi tersebut memang bersumber dari personil BPBD Kota Padangsidimpuan 
Sosialisasi yang dilakukan

oleh BPBD Kota Padangsidimpuan

kepada masyarakat dalam menangani

bencana adalah dengan melakukan

tindakan preventif misalnya tidak menebang pohon sembarangan

(ilegal loging), memberikan

sosialisasi serta simulasi dan bersahabat dengan alam dengan cara menjaga kebersihan dengan tidak membuang sampah ke sungai juga merupakan upaya yang harus dilakukan oleh masyarakat.

\section{Daftar Pustaka}

Haddow, G.D, dan Kims, H. 2008. Disaster Communications, In A Changing Media World. London. Elsevier

Idrus, Muhammad. 2009. Metode Penelitian Ilmu Sosial: Pendekatan Kualitatif dan Kuantitatif. Jakarta: Erlangga

Litlejohn, S.,\& Foss. 2006. Theories of communication edisi 7. Belmont, CA: Wadsworth

Ruben, Brent dan Lea Stewart. 2013. Komunikasi dan Perilaku Manusia. Jakarta. Raja Grafindo

Undang-Undang Nomor 24 Tahun 2007 Tentang Penanggulangan Bencana

Uripni, Christina. 2003. Komunikasi Kebidanan.

Jakarta:

Kedokteran

EGC 